\section{Calidad de los datos de salud ocupacional en América Latina y el Caribe ${ }^{1}$}

1 Se basa en: Organización Panamericana de la Salud, Programa de Salud de los Trabajadores de la División de Ambiente y Salud. Informe del Proyecto de Sistematización de Datos Básicos sobre Salud de los Trabajadores en Países de las Américas. Washington, DC: OPS; 1998.
La ausencia de datos confiables y sistematizados sobre la situación de salud de los trabajadores en América Latina y el Caribe constituye un problema de gran magnitud por la significativa pérdida económica y social que ocasionan los accidentes y las enfermedades de origen ocupacional. La falta de información adecuada y completa impide que las autoridades de salud y los empresarios tomen decisiones, o que los trabajadores y la opinión pública se movilicen para mejorar las condiciones laborales, disminuir los riesgos y prevenir esos accidentes y enfermedades. Para evaluar esa carencia, el Programa de Salud de los Trabajadores de la Organización Panamericana de la Salud (OPS-HEQ) coordinó el Proyecto de Sistematización de Datos Básicos sobre Salud de los Trabajadores en Países de las Américas. Los resultados, conclusiones y recomendaciones del Proyecto se fundamentan en los datos sobre la salud de los trabajadores recolectados en 10 países de la Región de las Américas (Barbados, Brasil, Colombia, Costa Rica, Chile, Jamaica, México, Panamá, Perú y Venezuela) con la colaboración del Instituto Salud y Trabajo, del Perú.

Los tres objetivos generales fueron: probar la Guía para la Sistematización de Datos Básicos sobre Salud de los Trabajadores para Países de las Américas (elaborada por el Centro de Salud Ocupacional de la Universidad Thomas Jefferson, de Filadelfia); sistematizar la información obtenida de ese modo para utilizar los resultados como base de hipótesis de trabajo de futuros análisis cualitativos o especializados, tanto de los países como de toda la Región; y determinar dónde se encuentra la información sobre la salud de los trabajadores en cada uno de los países estudiados y analizar la calidad de la misma.

Los datos nacionales se obtuvieron a partir de tres fuentes: los informes que los países elaboraron de acuerdo con la Guía mencionada, algunos informes que respondían a solicitudes específicas y las cifras que publica la Organización Internacional del Trabajo (OIT). Los siete criterios para consolidar la información fueron los siguientes: características de la economía, características de la fuerza de trabajo, organización y cobertura de los servicios de atención de la salud ocupacional, tipos de servicios e indemnizaciones que brindan las organizaciones prestadoras de los servicios, tipo de registro de accidentes de trabajo y enfermedades ocupacionales y forma de utilizarlos, costos de esos accidentes y enfermedades, y políticas nacionales de salud de los trabajadores. A continuación, se sistematizaron los datos y se volcaron en 42 tablas para establecer 
comparaciones entre los países o evaluar la situación en el ámbito nacional de cada uno.

El análisis de los datos sistematizados sobre la población trabajadora permite concluir que, en los países con buenos registros de salud ocupacional, una gran proporción de esa población desempeña sus tareas en sectores considerados de alto riesgo y asociados con tasas altas de accidentes y enfermedades crónicas. Además, los accidentes o enfermedades pueden estar registrados varias veces porque no existe una identificación única para cada trabajador y la mayoría de los trabajadores se encuentran fuera del sistema de seguridad social y, en consecuencia, no cuentan con servicios especializados de salud ocupacional. También resulta notable que, aunque existen datos sobre el número de niños trabajadores, no se cuenta con información sobre el efecto del trabajo sobre la salud de esos niños. Además, como el trabajo infantil se considera ilegal en la mayoría de los países, no hay protección legal ni servicios para mejorar la situación de ese grupo de la población.

Otras conclusiones indican que las diferencias de criterio para la clasificación, diagnóstico y registro de enfermedades y accidentes de trabajo entre instituciones y países, así como las modificaciones frecuentes de esos criterios, dificultan el análisis de las tendencias y los cambios en los perfiles de mortalidad y morbilidad laborales e impiden observar algunas de las faltas de equidad que favorecen los accidentes y enfermedades ocupacionales. Por otra parte, el carácter fragmentario de los datos dificulta estudiar la aparición de nuevos factores de riesgo ocupacional y las modificaciones de los factores de riesgo tradicionales, que son consecuencia de los cambios socioeconómicos y del proceso de innovación tecnológica en los países. Hay un gran contraste entre la limitada cantidad de datos que registran los países sobre el efecto del trabajo en la salud de la población trabajadora y el gran número de datos generales disponibles sobre la población económicamente activa, los salarios y beneficios que reciben los trabajadores y otros. Las discrepancias entre los datos proporcionados por los países a la OPS y los que maneja la OIT constituyen otra limitación para el análisis: los datos que recibe la OPS provienen principalmente de los ministerios de salud; en cambio, los datos de la OIT son enviados por los ministerios de trabajo que, a su vez, reciben la información de otras instituciones y empresas de acuerdo con la legislación de cada país.

Como resultado de la evaluación llevada a cabo, la OPS está elaborando un plan de trabajo para recopilar información más específica sobre la salud ocupacional en los países de la Región mediante un método que permita conocer los lugares de registro y fomente una coordinación más estrecha entre los responsables de manejar esa información. Con ese plan se intenta determinar si los datos se pueden comparar o si es posible homogeneizar el registro en los países y entre ellos, evaluar los sistemas o bancos de datos que ya existen en algunos lugares y estudiar su aplicabilidad en otros, reconocer las lagunas más importantes, y orientar el apoyo internacional para mejorar la calidad de la información. Por otra parte, se trata de coordinar esfuerzos con otros organismos internacionales, estudiar la factibilidad de utilizar nuevas opciones metodológicas para explotar la información existente, e identificar, evaluar y ampliar las experiencias que se están llevando a cabo en la Región. Por ejemplo, el Sistema de Información en Salud Ocupacional para la Vigilancia y la Detección de Riesgos Ocupacionales (SUAVIDERO) es un programa de informática que permite organizar las actividades de vigilancia de la salud ocupacional, el seguimiento de las lesiones y enfermedades laborales, y la atención de la discapacidad en el lugar de trabajo. La iniciativa comprende también otros aspectos como los de precisar y sistematizar los datos más confiables - entre ellos los accidentes mortales-, elaborar los indicadores correspondientes y estudiar los costos económicos de los accidentes y enfermedades ocupacionales.

\section{SYNOPSIS}

\section{The quality of occupational health data in Latin America and the Caribbean}

Work-related accidents and illnesses cause significant economic and social losses in Latin America and the Caribbean. However, the lack of reliable and systematized data on that situation makes it harder for health authorities and business operators to make decisions and for workers and the general public to take steps to improve working conditions, reduce risks, and prevent those accidents and illnesses.

To address that concern, the Program on Workers' Health of the Pan American Health Organization (PAHO) coordinated the Project on Systematizing Basic Data on Workers' Health in the Countries of the Americas. A report on the project issued in August 1998 contains results, conclusions, and recommendations based on data collected from 10 countries of the Region: Barbados, Brazil, Chile, Colombia, Costa Rica, Jamaica, Mexico, Panama, Peru, and Venezuela. The data were systematized and presented in 42 tables that allowed comparisons among the countries and evaluations of the situation in any one of the countries. Data from countries with adequate record keeping made it clear that many persons work in sectors with high rates of accidents and chronic disease. The research also found it is often hard to analyze trends and changes in labor mortality and morbidity and the conditions that increase the frequency of accidents and occupational diseases. That is because countries and institutions use a variety of approaches to classify, diagnose, and report diseases and occupational injuries, and also frequently modify their criteria. As a follow-up to this research, $P A H O$ is working to compile more specific information on occupational health in the countries of the Region, through an approach that would improve the quality of the information and make it easier to compare the data that is collected. 